\title{
DVA ISPRAĆAJA VLADANA DESNICE
}

\section{Monica Priante}

\author{
UDK: 821.163.42Desnica, V.:393.1“1967“ \\ Prethodno priopćenje
}

Sažetak: Na primjeru dvaju ispraćaja Vladana Desnice autorica prikazuje dihotomiju između dvaju mogućih shvaćanja smrti. Vladan Desnica umire u subotu 4. ožujka 1967. u Zagrebu u bolnici Rebro. Iz pregleda tiska jasno proizlazi kako se smrt odnosi samo na čovjeka Vladana Desnicu, dok Desnica-književnik smrću ne nestaje. Ta dvostrukost tjelesne smrti i javnog života očituje se i u govorima izrečenim tijekom Desničina ispraćaja. Prvi je održan na zagrebačkom Mirogoju 6. ožujka 1967., a drugi u Islamu Grčkom dan poslije, nakon čega je uslijedio ukop posmrtnih ostataka Vladana Desnice u crkvi sv. Đurđa u Kuli Stojana Jankovića. Na dvama ispraćajima pojavljuju se i drugi tipični elementi javnog sprovoda kao što su inkluzivan karakter sjećanja i afirmacija kulta ličnosti. Analizirajući stavove organizatora, postaje jasno da su javne pogrebne ceremonije često događaji na kojima se pokušava izbrisati sve tragove ideoloških, političkih i kulturnih sukoba.

Ključne riječi: smrt, povijest smrti, Vladan Desnica, ispraćaj, pogrebni rituali, dvostruki pogreb

$\int$ mrt razbija dinamičku ravnotežu privatnog i kolektivnog života, ali ta „praznina“ ovisi o važnosti položaja pokojnika u životu toga društva. Ispraćaj, odnosno, u ovom slučaju, dva ispraćaja posmrtnih ostataka ${ }^{1}$ predstavljaju odgovor društva na čin smrti. U svom radu o kolektivnoj reprezentaciji smrti antropolog Robert Hertz ističe da prakse povezane sa smrću zapravo nemaju individualan, nego društveni karakter. ${ }^{2}$ Također pokazuje kako je smrt traumatski događaj za društvo, kriza koju valja prevladati s pomoću rituala koji biološki događaj pretvaraju u društveni proces. Smrt se, dakle, smatra društvenom činjenicom, događanjem koje uzrokuje krizu, kako u užem obiteljskom okruženju tako i na širem planu klana, plemena ili lokalne zajednice. Zbog toga pogrebni obredi imaju i zadaću reorganizacije i preoblikovanja sjećanja na pokojnika, onkraj proteka uobičajenog vremena i dnevnog tijeka događaja.

$\overline{1}$ U tisku se uglavnom govori o ispraćaju ili ispraćaju posmrtnih ostataka Vladana Desnice. Tako npr. u Slobodnoj Dalmaciji stoji: „Desnica ispraćen iz Zagreba - povodom ispraćaja posmrtnih ostataka istaknutog književnika na Mirogoju...". Slobodna Dalmacija (Split), br. 6849, 7. 3. 1967., 7. Na drugom mjestu navodi se kako je „Vladan Desnica sahranjen u zavičaju u Islamu Grčkom“ te se spominju poznate osobe koje su prisustvovale „ispraćaju posmrtnih ostataka istaknutog književnika“. Slobodna Dalmacija (Split), br. 6850, 8. 3. 1967., 4.

2 Usp. Robert Hertz, „Contribution à une étude sur la représentation collective de la mort“, Année sociologique, 10/1907., 48-137. 
Pogrebni obredi, iako različiti u različitim grupama, društvima i kulturama, ispunjavaju određene društvene funkcije. Jedna od njih jest pomoć pri prevladavanju gubitka, a osobito u slučaju pogreba javnih osoba oni iskazuju brigu oko osiguravanja prisutnosti mrtvih među živima, naglašavajući opstanak pokojnika u svijetu živih. ${ }^{3} \mathrm{U}$ javnim ritualima (pogrebnim ili drugim) postoji tendencija da se simboličkim figurama osigurava memorijalna besmrtnost, zajamčena kultom sjećanja, što se zapravo i dogodilo u slučaju pogrebnih obreda nakon smrti Vladana Desnice.

Uz to, ovome očiglednom sloju interpretacije (evokacija i sjećanje na pokojnika) pridodaje se i drugi sloj, onaj koji odražava drugačiju težnju, tj. uzdizanje pokojnika kao primjera za cijelu zajednicu, govorima o njegovoj etičnosti, njegovim poučcima i nasljeđu koje ostavlja živima. Zapravo se na temelju tih aspekata tijekom javnih pogreba pojavljuje i inkluzivan karakter sjećanja kojima se nastoji pomiriti društvene podjele i ujediniti zajednicu u žalosti. I to je sastavni dio procesa afirmacije kulta ličnosti.

Tako, primjerice, pisac Čedo Prica u članku Prisutnost do kraja, objavljenom u Telegra$m u$, o Vladanu Desnici zapisuje sljedeće:

Kao pisac nije se pojavio da bi sa smrću nestao, već da bi ostao kao moralni i estetski kriteriji u hrvatskoj književnosti (...). Kao utjeha za naše fizičke rastanke, kao pomirenje za sve nesporazume što ih, izgleda, pisac nužno prima, kao nužni uvjet da bi izdržao, i da bismo mu se na kraju poklonili i prvi put bez uvjeta i nesporazuma razmislili o njegovu prisustvu među nama. ${ }^{4}$

Ili, kako je izjavio književnik Dragan Jeremić tijekom svoga govora na Mirogoju: „Ime Vladana Desnice ostat će zapisano zlatnim slovima u hrvatskoj i jugoslavenskoj književnosti“, uz zaključak kako će „Desnica, kao Srbin a pripadnik hrvatske književnosti biti uz Đuru Daničića, Josifa Pančića i Nikolu Teslu, kao zalog bratske slobode između Hrvata i Srba", čime ga, dakle, uzdiže i stavlja u idealan kulturni panteon.

Pogreb simbolički uklanja pojedinca s linije vremena i premješta svjetovnu osobu u domenu vječnog i svetog. Međutim, pored ovoga aspekta nalazimo i drugi, posebno zanimljiv aspekt, a odnosi se na izričaj „dva ispraćaja“. Korištenjem izrazom „dva ispraćaja“ želim se referirati na praksu dvostrukog pogreba predmodernih monarha, iako na to zasigurno nisu mislili organizatori Desničina ispraćaja. U predmodernim pogrebnim ritualima u Francuskoj ili Engleskoj, ${ }^{6}$ nakon ukopa kraljeva tijela, uslijedila je faza u kojoj se iskazivala počast i poštovanje lutku suverena odjevenog i ukrašenog svim atributima suvereniteta, kao da je pravi pokojni kralj. ${ }^{7}$ Ovakvom se inscenacijom željelo simbolički ispuniti opasnu institucionalnu prazninu koja se događa između kraljeve smrti te proglašenja i posvećenja njegova

\footnotetext{
Tara BAiley - Tony Walter, „Funerals against death“, Mortality, 21/2016., br. 2, 153-154.

Čedo Prica, „Prisutnost do kraja“, Telegram (Zagreb), br. 358, 10. 3. 1967., 10.

Slobodna Dalmacija (Split), br. 6849, 7. 3. 1967., 7.

6 Dvostruk pogreb (stvarnog tijela i lutka) prvi je put zabilježen u Engleskoj tijekom pogreba Edvarda II. (1327.) i u Francuskoj tijekom pogreba Karla VI. (1422.). Usp. Giovanni RiccI, „Le Corps et l'Effigie: Les Funérailles des Ducs de Ferrare à la Renaissance“, Civic Ritual and Drama (ur. Alexandra F. Johnston i Wim Hüsken), Amsterdam 1997., $175-178$.

7 Usp. Ralph Giesey, The Royal Funeral Ceremony in Renaissance France, Genève 1960.; Ernst Hartwig Kantorowicz, The King's Two Bodies. A Study in Mediaeval Political Theology, New Jersey 1981.
} 
nasljednika. U trenutku proglašenja kraljeva nasljednika obavljao se drugi pogreb (sprovod lutka), činom kojim je završavala faza ritualnog interludija.

Ovakva je praksa, uz modifikacije, nastavljena i u narednim stoljećima, a za primjer možemo uzeti sprovod prvog talijanskog kralja Vittorija Emanuelea II. 1878. godine. Nakon što je kraljevo tijelo sahranjeno, mjesec dana poslije uslijedio je drugi pogreb, na kojemu se koristio katafalk, kojim se aludiralo na prisutnost kraljeva tijela. ${ }^{8}$ Jasno je da u ovom slučaju nije bilo institucionalnih bojazni: nasljeđivanje prijestolja bilo je zajamčeno Ustavom, a svečano proglašenje novog kralja obično se izvršavalo odmah nakon smrti prijašnjega. Što je onda razlog dvostrukom pogrebu? Vratimo li se na ono što je ranije rečeno, motivacija za ovakvu praksu leži u činjenici da se ritualima, kao što je ovaj, željelo osigurati stvarnu prisutnost mrtvih u svijetu živih, na neki način trajno uklopiti pokojnika u zajednicu živih.

Međutim, pored svega navedenog, Carlo Ginzburg interpretira praksu dvostrukog pogreba na sljedeći način: prvi djeluje kao privremen ukop, onaj koji otvara put pročišćavanju tijela kontaminiranog dekompozicijom, dok drugi, sprovod samog simbola, ima karakter rituala uzvišenja, kojim se uvodi simbolički prikaz preminuloga (sada „pročišćenog“) na besmrtnom nebu junaka. ${ }^{9}$ Razlika između ovih dviju interpretacija vrlo je suptilna, ali se one djelomično i podudaraju: u prvom je slučaju smrt cirkularan proces, koji određenom transfiguracijom smješta mrtvog pripadnika u zajednicu živih, dok se u drugom smrt smatra prijelazom koji ukazuje na definitivno razdvajanje i čije se traumatične posljedice mogu samo ublažiti prisjećanjem. ${ }^{10}$ Očito je da postoji velika razlika između dvaju Desničinih ispraćaja i prethodno spomenutih primjera. Međutim, oba primjera imaju i nešto zajedničko, odnosno neka slična značenja, a to je upravo dihotomija između stvarnog i javnog tijela, ${ }^{11}$ koja je evidentna u tisku.

Zapravo, kada govorimo o dvostrukom pogrebu, istovremeno govorimo i o pitanju dvostrukosti vladareva tijela, koje uključuje i biološke i političke karakteristike. Ipak, slične pretpostavke možemo proširiti i na druge slučajeve poznatih i uvaženih osoba. Upravo zato smrt slavnih i moćnih pojedinaca ne predstavlja samo završetak njihove zemaljske egzistencije već ona vrlo često poprima i dodatne vrijednosti i značenja u političkom, društvenom i vjerskom smislu te se na kraju neizostavno veže uz opća razmatranja o vlasti, ideologiji ili društvenim vrijednostima. Stoga se, s jedne strane, smrt moćnog pojedinca izjednačava sa sudbinom svakog smrtnika, a s druge njegov kraj, odnosno, prije svega, sjećanje na njega postaje instrument u rukama živućih i pojedine se grupe njime koriste sukladno $s$ ciljevima koje žele postići. Tako smrt uvaženog pojedinca i sjećanje na njega sudjeluju u stvaranju procesa društvene distinkcije. U nekim slučajevima pogrebne prakse tako postaju modeli oblikovanja identiteta, legitimacija političkih odabira i predstavljaju cijele sustave vrijednosti.

U trenutku smrti mrtvi postaju odvojeni od vlastite individualne i prolazne dimenzije te nastavljaju svoju samostalnu i često trajnu ,javnu“ egzistenciju u sjećanjima i u imagi-

8 Usp. Alberto Mario Banti, „La memoria degli eroi“, Storia d’Italia. Annali, knj. 22: Risorgimento (ur. Alberto Mario Banti i Paul Ginsborg), Torino 2007., 645-659.

9 Carlo Ginzburg, Occhiacci di legno, Milano 2011., 84-86.

10 A. M. BAnti, „La memoria degli eroi“, 653.

11 Usp. E. H. Kantorowicz, The King's Two Bodies; Nicole Marafioti, The King's Body, Toronto 2014. 


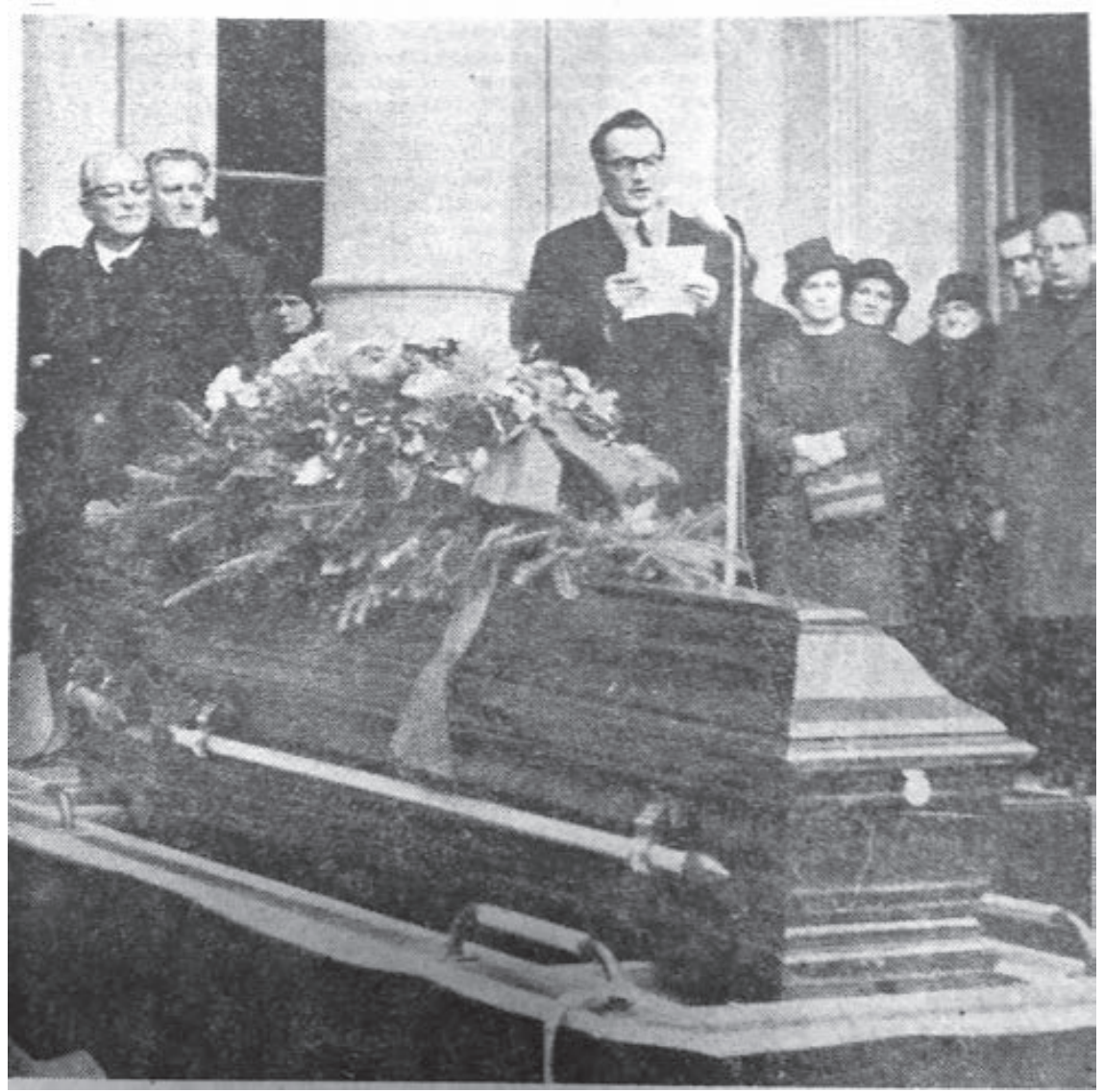

Sl. 1. Oproštaj od Vladana Desnice ispred mrtvačnice na zagrebačkom Mirogoju

nariju živih. Začetak te javne egzistencije zapravo je početak pogrebnih rituala: ispraćaji i komemoracije u tiskovinama. To potvrđuju, primjerice, riječi preuzete iz oproštajnog govora Pere Budaka na Mirogoju:

Djelo Vladana Desnice živjet će i dalje svojim posebnim književnim životom. U intimnim časovima čitanja on će se, živ i prisutan, susretati i poslije svoje smrti sa tisućama i tisućama čitalaca. Tako njegova fizička smrt postaje samo prividna, efemerna i ništavna, jer je svojim djelom, rezultatima svog uma i srca, uspio prolongirati svoj život unedogled. ${ }^{12}$

Potvrđuju to i riječi objavljene u Novom listu: „Kad govori o proljeću, kad govori za ljubav i protiv smrti, ostaje tu, odmah pred nas." ${ }^{\text {"13 }}$

Pored toga, željela bih istaknuti i drugi element koji se tiče pogrebnih rituala i pojma dvaju pogreba, a tu mislim prije svega na „spacijalni element“. U proučavanju pogrebnih rituala moramo uzeti u obzir dvije karakteristične sastavnice: temporalnu i spacijalnu. Prvi, temporalni element, obilježava vrijeme bdijenja, pokopa, ispraćaj ili ispraćaje, žalovanje itd. Drugi, spacijalni element, odnosi se na činjenicu da su neka mjesta u pogrebnim ritualima 
posebno značajna, npr. kuća/bolnica, groblje, put od kuće/bolnice do groblja, grobno mjesto (npr. izbor ukopa na mjestu podrijetla/rođenja ili na mjestu gdje se živjelo te također važnost repatrijacije smrtnih ostataka na rodno tlo). Mjesta na kojima se odvijaju različiti dijelovi rituala imaju snažnu kulturnu i društvenu komponentu, kao što je npr. progresivno širenje medikalizacije smrti, koja dovodi do toga da većina smrti biva premještena u bolnicu pa se ona više uglavnom ne zbiva u kući. Zapravo, ako se u prošlosti kulminacija kolektivnog momenta odvijala uz smrtnu postelju umirućeg, na prijelazu iz 19. u 20. stoljeće taj moment postaje posljednji pozdrav, u kojemu obično sudjeluje cijela zajednica ili uži krug rod-

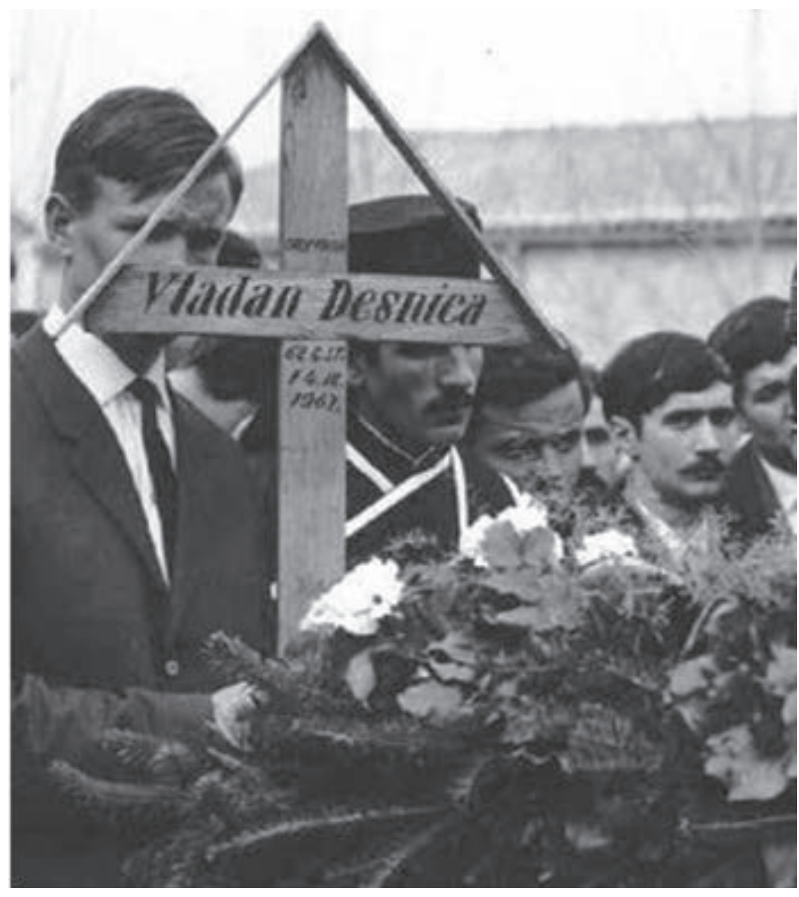

Sl. 2. Oproštaj od Vladana Desnice u Islamu Grčkom bine, prijatelja i poznanika. Pogreb, prijelaz između dvaju svjetova - svijeta živih i svijeta mrtvih - postaje mjestom koje poprima visoko simboličko značenje, mjesto prijelaza na kojem i preminuli i njegova rodbina obavljaju čin razdvajanja i pridružuju se novom svijetu.

No, što se tiče mjesta ukopa, odnosno grobnica, one nisu samo mjesto pokopa pojedinca, nego su i mjesta gdje se čuvaju i na okupu nalaze posmrtni ostaci članova cijele obitelji, mjesta koja označavaju i zajedništvo te obitelji. Također, ako dodatno proširimo ovaj diskurs, grobnica može biti i znak zajedništva cjelokupne lokalne zajednice koja prima i dočekuje pokojnika na svom posljednjem počivalištu. ${ }^{14}$

Zbog njihova trajnog karaktera ${ }^{15}$ i prisutnosti pokojnikâ koji su ondje sahranjeni, grobnice zapravo mogu predstavljati središnju točku veze između živih i mrtvih te njihova specifičnog lokalnog okruženja. ${ }^{16}$ Čak i u novije vrijeme talijansko javno mnijenje govorilo je o dvama ispraćajima. U Italiji bio je poznat ispraćaj čuvenog glumca Antonija de Curtisa, poznatijeg pod imenom Totò, 1967. godine. Nedavno je, 2015. godine, dva ispraćaja imao i poznati napuljski pjevač Pino Daniele - oba između Rima i Napulja, kako bi se naglasila spacijalna i simbolička pripadnost objema lokalnim zajednicama. Zanimljivo je primijetiti da u ovim slučajevima nemamo samo spacijalnu dvostrukost nego i simboličku jer se radi o primjeni različitih simbola (lokalnih, vjerskih i političkih) i običaja povezanih s određenim teritorijem.

14 Usp. Kate Woodthorpe, „Sustaining the contemporary cemetery: implementing policy alongside conflicting perspectives and purpose“, Mortality, 16/2011., br. 3, 259-276.

15 Julie RugG, „Defining the place of burial: what makes a cemetery a cemetery?“, Mortality, 5/2000., br. 3, 264.

16 Usp. K. Woodthorpe, „Sustaining the contemporary cemetery“, 264-269. 


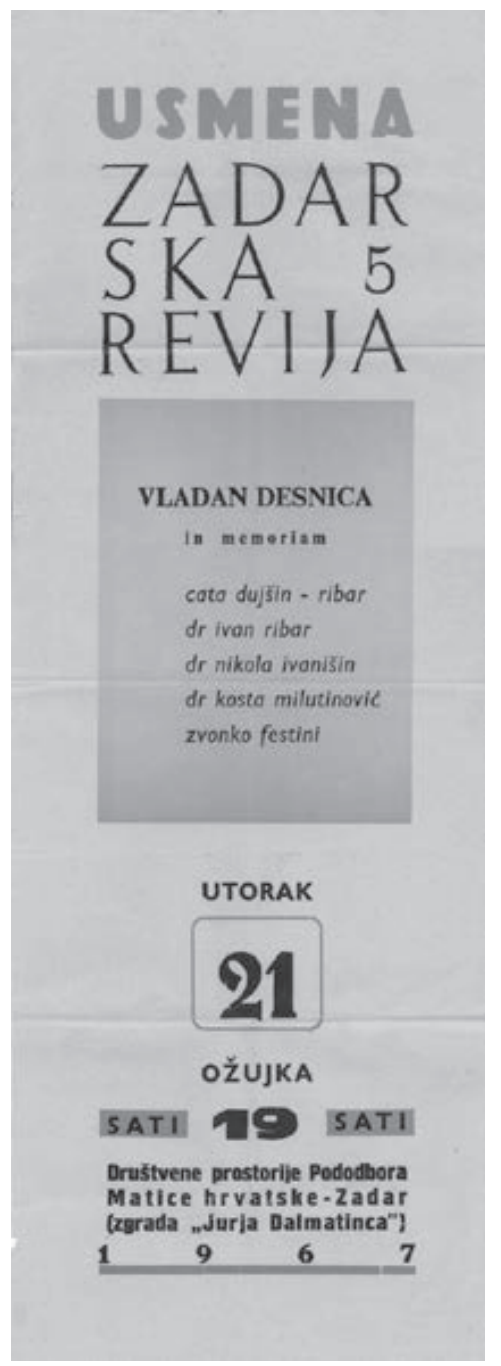

Sl. 3. Reprodukcija plakata

Usmena Zadarska revija.

Vladan Desnica in memoriam

Jasno je da u tom smislu dva ispraćaja Vladana Desnice izražavaju i dvostrukost između Zagreba - grada koji ga je usvojio i u kojemu je živio - i njegova rodnog kraja, kako to naglašava Narodni list: „Iako nastanjen u Zagrebu, Vladan Desnica održavao je stalne i čvrste veze s rodnim gradom i krajem, kamo je uvijek navraćao. ${ }^{\text {"17 }}$

Nadalje, smrt slavnih osoba predstavlja i ceremonijal za javnost koji utječe i na odvijanje uobičajenih pogrebnih praksi te u tom slučaju imamo model posljednjeg ispraćaja koji je uobičajen za javne osobe u 20. stoljeću. ${ }^{18}$

Sada bih se htjela osvrnuti i na specifičnu analizu nekoliko obilježja pogrebnih rituala Vladane Desnice rekonstruiranih na temelju novina i osobnih sjećanja obitelji Desnica. Općenito, gotovo svake novine toga vremena prenosile su vijest o Desničinoj smrti. Obično je vijest bila popraćena fotografijom ili portretom, ali sve to varira u odnosu na tiskovinu o kojoj je riječ. Također i duljina teksta i opreme variraju: od nekoliko redova do pola ili cijele stranice. ${ }^{19}$

Većina listova izvješćuje o Desničinoj smrti s kratkom piščevom biografijom. Obično na početku nalazimo podatke o Desničinu životu (rođenje, obrazovanje i studiji u Zagrebu i u Parizu, karijera u advokaturi, sudjelovanje u NOB-u i, naravno, literarna karijera, njegov opus, prijevodi...). Osim što donose Desničine glavne intelektualne smjernice, autori članaka također stvaraju i liniju kontinuiteta između sadašnjosti i budućnosti, između Desničina opusa i njegova nasljeđa budućim generacijama. Zapravo, u većini slučajeva, uz opis Desničina književnog stvaralaštva, nalazimo i pojedinosti koje uključuju piščev background (društveni i kulturni), čime ga se smješta u društveni prostor i vrijeme. O privatnoj sferi Desničina života nalazimo nekoliko podataka samo u Politici, jedinom listu koji ne govori o Desnici samo kao o književniku. Zapravo ni u Politici ne nalazimo puno, tek nekoliko detalja o njegovoj rodbini i o njegovoj ljubavi prema glazbi:

Kako su mu preci po majci bili pomorci to je u njemu ostao nemir za morem koga muzički doživljava u širokoj skali ritmova i tonova. Taj afinitet za muziku toliko je preovladao da

\footnotetext{
17 Narodni list (Zadar), br. 806, 11. 3. 1967., 5.

18 Michel RaGon, Lo spazio della morte. Saggio sull'architettura, la decorazione e l'urbanistica funeraria, Napoli 1986. 160.

19 Pored toga, nalazimo i tekstove u književnim časopisima. Usp. Miroslav Šıcel, „In memoriam, Književno djelo Vladana Desnice“, Republika (Zagreb), 23/1967., br. 5, 204-205.
} 
se hteo njoj i posvetiti, ali porodica je mislila da je po građanskom naslednom redu predodređen za pravo. ${ }^{20}$

Mnoge novine sadrže dijelove i citate iz Desničinih književnih djela, osobito iz romana Proljeća Ivana Galeba. ${ }^{21}$

Poznato je da je Vladan Desnica umro u subotu 4. ožujka 1967. u Zagrebu u bolnici Rebro. No, novine ne govore o njegovoj bolesti i smrti. Javlja se tek uobičajena fraza „nakon duge i teške bolesti“ 22 a obično je piščeva smrt opisana kao „iznenadna i prerana“. Dakle, ne navodi se ništa što bi se odnosilo na bolest, tjelesnu smrt ili tjelesno propadanje. U takvoj šutnji prepoznajemo i proces uklanjanja smrti i umiranja iz vidokruga zajednice, koji je na djelu u 20. stoljeću, i posljedično odbijanje razgovora o smrti. ${ }^{23}$

No, s druge strane, nalazimo obilne informacije o raznim elementima društveno prihvatljivog oblika sjećanja (poetika, stil, jezik, književni opus). Možda je zanimljivo spomenuti u tom pogledu da članci koji zapravo najviše govore o Desničinoj intimnosti, koji ga čak i fizički opisuju, u stvarnosti nisu povezani s neposrednom piščevom smrti i sa samom sprovodnom počasti, nego su to ponajprije sjećanja na sastanke s Desnicom za njegova života. Dakle, sve reference na fizičko tijelo Vladane Desnice odnose se na njega dok je bio živ.

Referiram se na dva članka. Prvi je članak Dimitrija Mašanovića Dva susreta sa Vladanom Desnicom, objavljen u Književnim novinama. ${ }^{24} \mathrm{U}$ njemu nalazimo opis prvoga susreta iz srpnja 1956. u Desničinu stanu u Zagrebu te drugoga na simpoziju o suvremenom jugoslavenskom romanu u rujnu 1965. Drugi članak, Susreti s Vladanom Desnicom - videnja i saznanja Branka Marjanovića, objavljen je u Narodnom listu. ${ }^{25}$ U njemu su opisana tri susreta: prvi u Islamu Grčkom devet godina prije nastanka teksta, drugi u Splitu dvije godine prije toga i treći, zadnji susret, također u Splitu, mjesec dana prije Desničine smrti. Autor navodi kako su se u ovome posljednjem već mogli primijetiti tužni znakovi približavanja kraja:

Nema ni mjesec dana da sam ga zadnji put sreo... Da Vladan Desnica nije ni pomišljao još da bi mogao umrijeti, - operacija je uspjela, sad je sve dobro, muči me samo čir na želucu! - rekao mi je i - ako me namjerno nije obmanuo iz nekih svojih razloga ili obzira, tajnih i nedokučivih - mogao sam osjetiti u glasu mu ono naivno pouzdanje svih ljudi, kojima smrt stoji kraj ramena. ${ }^{26}$

O dvama ispraćajima u onodobnom tisku nemamo puno informacija. Prvi je bio na Mirogoju u ponedjeljak, 6. ožujka 1967. poslijepodne. Bio je prisutan „veliki broj Zagrepčana“, „mnogobrojni književnici, umjetnici i kulturni javni radnici glavnoga grada Hrvatske, kao

$\overline{20}$ Politika (Beograd), br. 19186, 5. 3. 1967., 3.

21 „Vladan Desnica Igre Proljeća i smrti. Odlomci iz romana: Proljeća Ivana galeba“, Novi List (Zadar), br. 54 , 7. 3. 1967., 8; „Vladan Desnica ‘Dvopjev' (Ulomci iz romana 'Proljeća Ivana Galeba')“, Narodni list (Zadar), br. $806,11$. 3. $1967 ., 5$.

22 Slobodna Dalmacija (Split), br. 6848, 6. 3. 1967., 2; Narodni list (Zadar) br. 806, 11. 3. 1967., 5; Borba (Zagreb), br. 62, 5. 3. 1967., 4.

23 Norbert Elias, The Loneliness of the Dying, Oxford 1985., 11-12.

24 Književne novine (Beograd), br. 257, 18. 3. 1967., 1, 12.

25 Narodni list (Zadar), br. 806, 11. 3. 1967., 5.

26 Isto. 


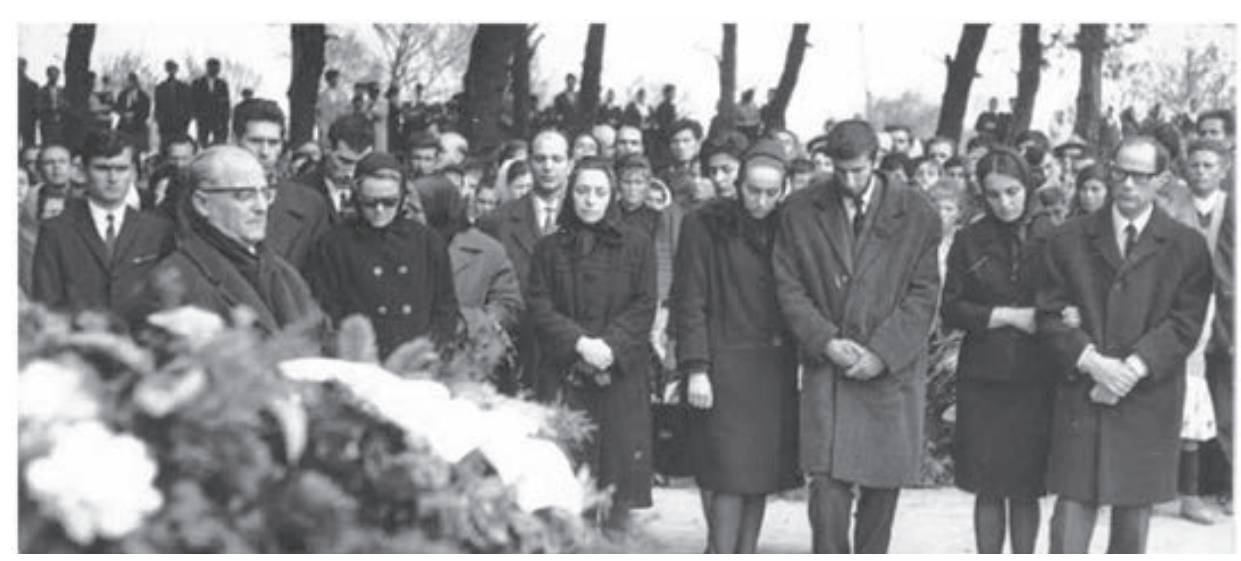

Sl. 4. Ispred odra Vladana Desnice

i članovi konzularnog kora" te članovi odbora za sahranu. ${ }^{27}$ Potonji su bili: Dalibor Brozović, Pero Budak, Ivo Frangeš, Jure Kaštelan, Slavko Mihalić, Vlatko Pavletić, Čedo Prica, Petar Šegedin i Franjo Švelec. ${ }^{28}$ Članovi Društva književnika i pokojnikovi prijatelji držali su počasnu stražu uz odar. Posljednju počasnu stražu kraj odra Vladana Desnice držali su književnici Jure Kaštelan, Petar Šegedin, Čedo Prica, Milivoj Slaviček i Tomislav Ladan. ${ }^{29}$ Među onima koji su održali govore bili su: Dragan M. Jeremić uime Udruženja književnika Srbije i Pero Budak uime Društva književnika Hrvatske i Matice hrvatske. ${ }^{30}$ Nakon toga, piše u Politici, pokriven „vencima i cvećem, kovčeg sa telom Vladana Desnice stavljen je potom u automobil koji će ga preneti u njegov rodni kraj Zadar, gde će biti sahranjen“. ${ }^{31}$

Drugi ispraćaj i sahrana odvili su se u Islamu Grčkomu u poslijepodnevnim satima utorka, 7. ožujka 1967. Prisustvovali su im brojni kulturni i javni radnici te velik broj građana iz sjeverne Dalmacije. Kako je izvijestila Slobodna Dalmacija:

Već u ranim prijepodnevnim satima počele su u Islam Grčki stizati kolone autobusa i automobila iz Zadra i okolnih mjesta s poštovaocima Desničina književnog stvaralaštva koji su željeli da mu odaju posljednju počast. ${ }^{32}$

Kako navodi Uroš Desnica, piščev sin:

U Islamu Grčkom obred je počeo ispred Kule, kad je odar bio pred glavnim ulazom u povijesni dio kompleksa, ispred ulaza u prostoriju „Straža“, a ispod same Kule Jankovića, na kojoj se vila crna zastava žalosti. Već je ovdje bilo jako puno naroda, koji je ispunio gotovo cijelu Veliku avliju. ${ }^{33}$

Ili, kako je to emfatično naglasila Slobodna Dalmacija:

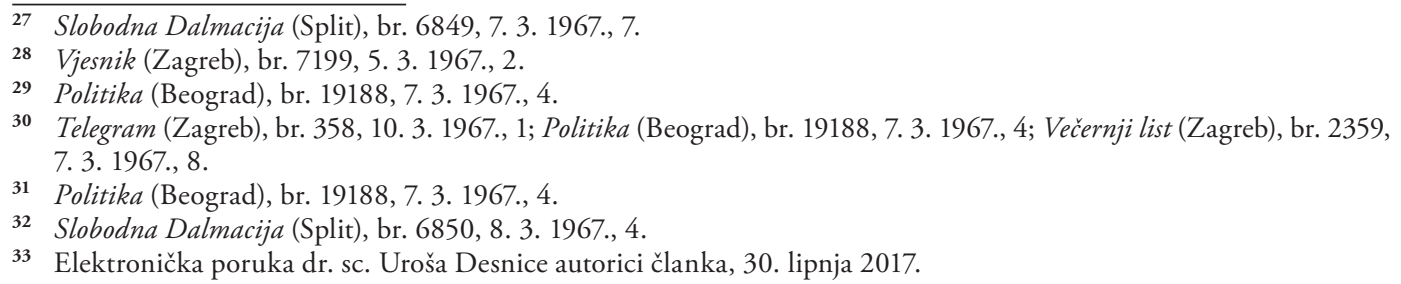




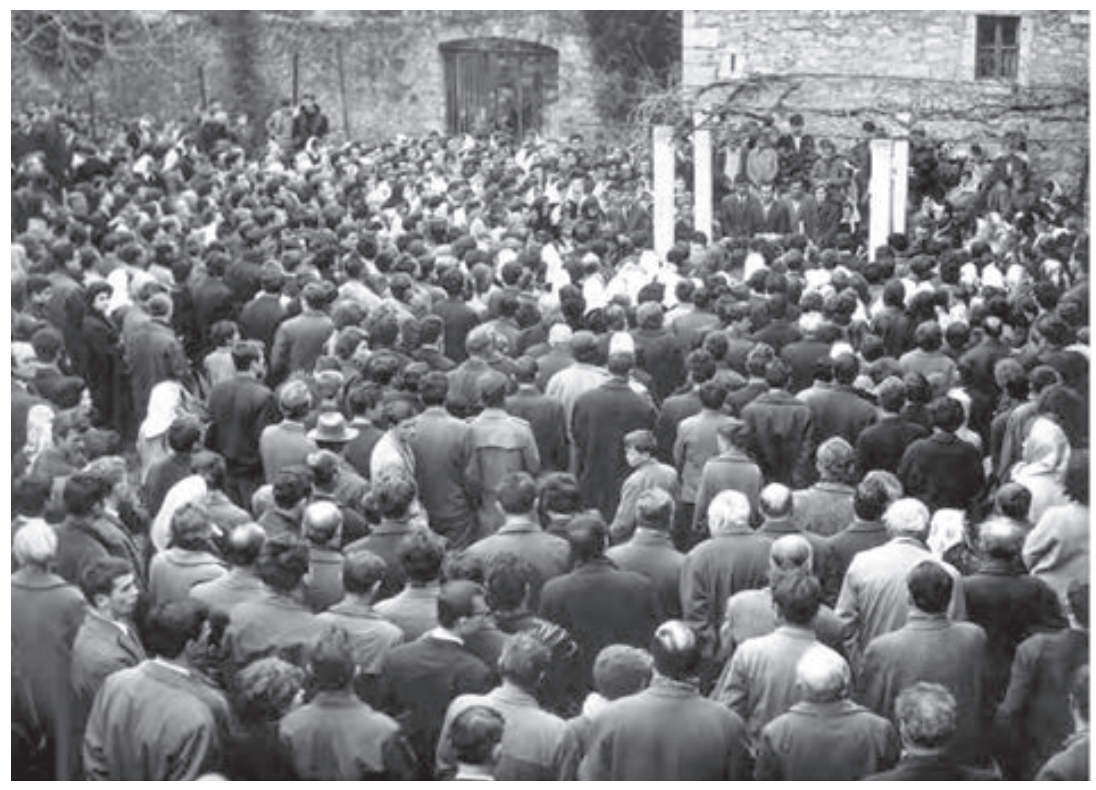

Sl. 5. Okupljeno mnoštvo ispred Kule Stojana Jankovića u Islamu Grčkom na sprovodu Vladana Desnice

Na kuli legendarnoga hajdučkog vođe Janković Stojana u Islamu Grčkom vijorila se danas crna zastava. Žitelji Ravnih kotara i sjeverne Dalmacije opraštali su se od svog uglednog sina, istinskog književnika Vladana Desnice, potomka slavnih serdara i hajduka tog kraja. ${ }^{34}$

Zatim se žalobna povorka od nekoliko stotina prisutnih kretala glavnom cestom kroz Islam Grčki, do mjesne osnovne škole i biste Sime Matavulja. Govore su održali, među ostalima, profesor Filozofskog fakulteta u Zagrebu Nikola Ivanišin uime Matice hrvatske i Filozofskog fakulteta u Zadru, Dalibor Brozović uime pisaca okupljenih oko časopisa Krugovi i Dalibor Cvitan uime Društva književnika Hrvatske. ${ }^{35}$ Okupilo se i mnogo učenika, a neki su i pročitali svoje govore.

Potom je povorka stigla do „gumna“, smještenog između sjevernog zida kompleksa i starog groblja sa crkvom sv. Đurđa. I ondje je govorilo više ljudi, među ostalima i dr. Vinko Foretić uime naroda sjeverne Dalmacije, ${ }^{36}$ a bili su prisutni i predstavnici općina Zadar i Benkovac. ${ }^{37}$ Zatim je odar došao pred pročelje crkve sv. Đurđa te je konačno smrtno tijelo Vladana Desnice položeno u obiteljsku grobnicu u kapeli Kule Jankovića pored supruge Ksenije.

Stoga možemo zaključiti da posljednji ispraćaj Vladana Desnice spada u tipične ceremonije toga vremena. Međutim, zanimljiv je zbog dvostrukog ispraćaja u spacijalnom smislu - Zagreb i Zadar - te u simboličkom smislu, koji je vidljiv u raznolikosti sudionika, organizatora, govornika i vrsta pogrebnih govora. Uz to, dvostrukost dvaju tijela Vladana

\footnotetext{
34 Slobodna Dalmacija (Split), br. 6850, 8. 3. 1967., 4.

35 Isto.

36 Isto.

37 „Javna Zahvala“, Narodni list (Zadar), br. 807, 18. 3. 1967., 8. Prema osobnim sjećanjima, među govornicima bili su i Jovo Vujasinović i Dušan Brkić. Zahvaljujem dr. sc. Urošu Desnici na ovom podatku.
} 
Desnice vidljiva je i u tisku, u kojem se pojavljuje razdvajanje fizičkog (posmrtni ostaci koji su završili svoje postojanje) i simboličkog tijela (književnog i društvenog), koje u tom trenutku započinje svoj samostalan put:

Književna riječ Vladana Desnice, ostala među nama poslije prerane i neočekivane smrti, javlja se kao njegov novi život. Gotovo bih rekao i kao jedini njegov život: onaj najbolji, koji je sam on odabrao i sam oživio. Taj život - riječ nije nepoznata u nas. Njeno svjetlo je već bilo vidno prisutno u našoj književnosti, ali sada - poslije njegove smrti - biva još čišće, a njegov sjaj još vidniji. ${ }^{38}$

\section{$\cos$}

\section{Izvori i literatura}

\section{Izvori}

Borba (Zagreb), 1967.

Književne novine (Beograd), 1967.

Narodni list (Zadar), 1967.

Novi list (Rijeka), 1967.

Politika (Beograd), 1967.

Republika (Zagreb), 1967.

Slobodna Dalmacija (Split), 1967.

Telegram (Zagreb), 1967.

Večernji list (Zagreb), 1967.

Vjesnik (Zagreb), 1967.

\section{Literatura}

Tara Bailey - Tony WaLter, „Funerals against death“, Mortality, 21/2016., br. 2, 149-166.

Alberto Mario Banti, „La memoria degli eroi“, Storia d'Italia. Annali, knj. 22: Risorgimento (ur. Alberto Mario Banti i Paul Ginsborg), Torino 2007., 637-664.

Norbert Elias, The Loneliness of the Dying, Oxford 1985.

Ralph Giesey, The Royal Funeral Ceremony in Renaissance France, Genève 1960.

Carlo Ginzburg, Occhiacci di legno, Milano 2011.

Robert Hertz, „Contribution à une étude sur la représentation collective de la mort“, Année sociologique, 10/1907., 48-137.

Ernst Hartwig Kantorowicz, The King's Two Bodies. A Study in Mediaeval Political Theology, New Jersey 1981.

Nicole Marafioti, The King's Body, Toronto 2014.

Michel Ragon, Lo spazio della morte. Saggio sull'architettura, la decorazione e l'urbanistica funeraria, Napoli 1986.

$\overline{38}$ Petar Š Egedin, „Riječ - život“, Telegram (Zagreb), br. 358, 10. 3. 1967., 1. 
Giovanni Ricci, „Le Corps et l'Effigie: Les Funérailles des Ducs de Ferrare à la Renaissance“, $C i$ vic Ritual and Drama (ur. Alexandra F. Johnston i Wim Hüsken), Amsterdam 1997., 175-201.

Julie RugG, „Defining the place of burial: what makes a cemetery a cemetery?“, Mortality, 5/2000., br. 3, 238-259.

Kate Woodthorpe, „Sustaining the contemporary cemetery: implementing policy alongside conflicting perspectives and purpose“, Mortality, 16/2011., br. 3, 259-276.

\section{$\cos$}

\section{Two MEMORIAl SERVices for VladAN Desnica}

Using the two different memorial services held for Vladan Desnica as a starting point, the author demonstrates the dichotomy between two contrasting views of death. Vladan Desnica passed away on Saturday, March 4th 1967 in the Rebro Hospital in Zagreb. An overview of the reporting of his passing makes it clear that it is Desnica the man who is taken, whereas Desnica the author is beyond the reach of death. This duality of physical death and public life is reflected in the eulogies given during Desnica's memorial service. The first one of the two was held at the Mirogoj cemetery in Zagreb on March 6th 1967, while the other took place in Islam Grčki the following day and was immediately followed by the interment of Desnica's remains in the church of St. George in the Stojan Janković Tower. The way a culture chooses to remember its dead reflects the nature and the character of that culture, while the way a society uses death becomes an indicator of its values. For instance, the removal of death and dying from the view of the community at large, and the consequent refusal to discuss death was evident throughout the 20th century. Thus, the division between Vladan Desnica as a (dead) body, the details of which are scarcely reported on, and Desnica as the writer becomes evident in the press. Nothing we would be reluctant to talk about or depict (illness, decay, death) is referred to, whereas the socially acceptable forms of memory (poietics, style, language, literary ouevre) are cited extensively. Finally, the two memorial services exhibit other typical feautres of a public funeral, such as the inclusive nature of memory and the affirmation of the cult of personality. Public rituals, funerals included, can be analysed from numerous points of view - that of the organizer, the participant, the observer and/or the commentator - yet they inevitably have an inclusive and an exclusive element to them. By analysing just the attitudes of the organizer, a frequent tendency of expunging all traces of ideological, political or cultural conflict becomes evident. Similarly to the united front presented by the grieving family on the private level, on the public level, these ceremonies were often supposed to be visibly inclusive. Thus, it was stated that Vladan Desnica's name is "written in golden letters in the history of Croatian and Yugoslav literature" and listed in the cultural pantheon "alongside Đuro Daničić, Josif Pančić and Nikola Tesla as another token of brotherly freedom between the Croats and the Serbs".

Key words: death, the history of death, Vladan Desnica, memorial service, funerary rites/rituals, double funeral 